AWEJ for Translation \& Literary Studies, Volume3, Number2.May 2019

DOI: http://dx.doi.org/10.24093/awejtls/vol3no2.7

Pp.66 -77

\title{
“Jane Eyre’s Morality": A Kohlbergian Reading
}

\author{
Ali Sabri Mohammad Abu Hassan \\ Department of English, Faculty of Languages and Communication \\ Sultan ZinalAbidin University \\ Terengganu, Malaysia \\ Mohd Nazri Latif Azmi \\ Department of English, Faculty of Languages and Communication \\ Sultan ZinalAbidin University \\ Terengganu, Malaysia
}

\begin{abstract}
:
Classified as a bildungsroman novel, Brontë's Jane Eyre (1847) is a work of fiction which deals with the moral development of the main character as an essential ingredient of the genre. Jane's journey towards maturity and independence is a long rocky way that shapes her identity and finally harmonizes her with society. Through many stations in her journey, Jane has to make tough moral choices and decisions to obtain healthy moral reasoning. Thus, this paper is meant to trace the protagonist's moral development in the light of Lawrence Kohlberg's moral theory. Jane's journey starts when she is ten years old, and ends at the age of thirty. At the end of the novel, Jane is married and has a child aged ten. Her twenty-year-journey locates her in the three consecutive stages of moral development. Her twenty-year-journey locates her in the three consecutive stages of moral development. Depicting the influence of the main and minor characters in the novel, this paper seeks to illustrate how Jane develops a sense of moral reasoning and acts accordingly.
\end{abstract}

Keywords: bildungsroman, conventional morality, kohlberg's moral development, postconventional morality, preconventional morality

Cites as: Abu Hassan, A.S.M., \& Azmi, M.N.L. (2019). "Jane Eyre's Morality”: A Kohlbergian Reading. Arab World English Journal for Translation \& Literary Studies, 3 (2) 66 77. DOI: http://dx.doi.org/10.24093/awejtls/vol3no2.7

Arab World English Journal for Translation \& Literary Studies

ISSN: 2550-1542 |www.awej-tls.org 


\subsection{Introduction}

Bildungsroman is the term labels to literary works that trace the protagonist's journey from childhood to adulthood, from immaturity to maturity. When Murfin and Ray (1997) describe the genre, they state that it is a novel that traces the protagonist's process of development from the early stages of his life to maturity, the process continues until he comes to understand and perceive his position and his function in the world. Hirsch (1979) has a narrower description when she states that the genre refers to novels that depict the "all-around" development of the protagonist, where the individual develops and grows within the frame of a "defined social order" (pp.293-311). The genre also focuses on the protagonist's change through a journey, which might be physical or metaphorical, that reshapes his/her character; it mainly focuses on the protagonist's psychosocial and moral growth. Sometimes, the protagonist is already an adult but not yet mature. The term is a combination of "Bildung" meaning development, and "roman" meaning novel. Johan Wolfgang von Goethe's Wilhelm Meister's Apprenticeship, written in 1795, is considered to be the prototype of this genre and a primary resource for every study in the field. Bildungsroman novels are meant to take the readers from their comfortable chairs to join the protagonist with his/her journey which is usually a journey full of difficulties, challenges, and tests. These obstacles the protagonist faces are meant to form his/her growth and transformation, taking him/her to a state of self and social reconciliation.

\subsection{Methodology}

\subsubsection{Kohlberg's Theory of Moral Development}

Lawrence Kohlberg (1958) presented his theory of moral development which states that the individual has to go through universal consecutive stages of moral development. The different previous experiences of solving problems play a major role in developing the way we think (Hayes, 2013). The individual must be mentally engaged to pass to a higher stage of moral development because every higher stage activates more complex and high-level thinking. Personal experiences, as well as, social attitudes are principal considerations to complete the moral development in each stage (Power, 2004). The ability to make a judgment or a decision is an indicator of moral reasoning which determines our behavioral conduct. According to Kohlberg, it is not the decision itself that matters, but how the decision is made. Kohlberg (1981) asserts that moral behavior is the result of many factors, among them is the moral reasoning or judgment which acts as the most effective element (Reynolds, 2007). Similarly, Tsui (2001) referred to the universal acceptance of Kohlberg's theory as it establishes the practical and experimental confirmation of the moral reasoning and its effect on the moral behavior. Talwar (2011) was more specific than Reynolds when he explained that the meaning of reasoning and judgment is the process in which the individual can evaluate, interpret the moral situation, and then conduct a moral behavior accordingly.

Kohlberg (1971) believes that individuals in any given society practice universal principles of morality whatever their culture is. He says that there are thirty common and mutual fundamental categories, concepts, or principles like law, property, authority, trust, and so on, that people have to deal with in their lives. Kohlberg's claim is that people in all cultures are encountered with struggles within these universal realms. Since there are worldly moral issues and struggles, the moral stages of individuals are usually measured by staging dilemmas that are intended to be settled in any culture. In this context, Kohlberg (1984) emphasizes that moral judgment occurs 
according to a universal order of stages where the judgment evolves through three levels: preconventional, conventional, and post-conventional. Each level includes two stages which are further explained as follows:

\subsubsection{Pre-conventional level}

Preconventional moral reasoning is the base of Kohlberg's hierarchy of Moral Development. This level as the other two levels, includes two stages, where the second stage is always a more complicated and advanced socio-moral view than the former stage (Kohlberg, 1984).

Stage one of this level is known as the Obedience and Punishment Orientation Stage (Kohlberg, 1984). This stage is characterized by individuals, especially children, who do what they have been told to do in order to avoid punishment by adults whom they look at as authority. The driving force at this stage is the individual's egocentric standpoint, that is to say, the individual is much more concerned about his own interest rather than others (Kohlberg, 1984; Kuhmerker, 1991). Obeying the rule is not driven by an internalized understanding of what is safe for him/her but by fear of being punished.

The second stage of this level is known as the Naively Egocentric Orientation Stage or as the Exchange Stage. In this stage, individuals, particularly children, decide what is right and what is wrong from a tangible individualistic perspective (Kohlberg, 1984; Kuhmerker, 1991). In this stage, children realize that others have their own interests as well. Hence, they tend to exchange their interests with others and focus on fair deals. For example, a child will give his sister a piece of his cake, if she gives him a piece of her chocolate. So, the favor is done conditionally, and only if something in return is gained (Kohlberg, 1984; Kuhmerker, 1991).

\subsubsection{Conventional level}

The next level of moral reasoning is Conventional Moral Judgment. In this stage, the rules and the expectations of those who are close to the individual like family and friends, are unconsciously assimilated within the individual, and his moral judgments and behavioral actions are governed by how they expect him to act. (Colby \& Kohlberg, 1987).

The first stage of this level is known as, Good-boy/Good-girl Orientation. In this stage, the social perspective is the driving force that leads the individual's conduction of making relationships with others, and where he/she gives the priority for mutual feelings, expectations, and agreements over the personal interests. The act of doing what is right is mainly to keep relations with others and to reach the level of expectations of those around him/her. To maintain relations with others, the individual usually follows certain principles such as; trust, loyalty, gratitude, caring and concern of others (Kohlberg, 1984; Kuhmerker, 1991). It is worthy of mentioning here that, the individual may behave caring, trustworthy, and loyal to those in his circle, but might not behave the same outside his/her social group.

The other stage of this level is best identified as Authority and Social Order Maintaining Orientation (Kohlberg, 1984; Kuhmerker, 1991). During this stage, individuals can differentiate between a wider societal perspective and interpersonal bonds:- they are also capable of recognizing the social system as establishing and generating rules. For individuals to fulfill their duties and 
requirements towards their society is considered the right conduction. Individuals at this stage obey laws and rules, hardly willing to break them, while they also contribute to the society to keep it as a unit. (Kohlberg, 1984; Kuhmerker, 1991). For instance, the individual concedes the far side of rules, and he perceives rules such as jumping a red light are enforced keep order in the society, and he accepts it in order to sustain the structure of the society. Law and order are meant to stay. Otherwise, chaos will ensue.

\subsubsection{Post-conventional level}

In this level, the individual is free from the restrictions of the past two levels; the authority of the adult around and the social norms. The individual's reasoning of morality is no longer subjected to the authority around him/her or to the laws and rules enforced by the society. In this level, the driving force behind moral reasoning is subjective, and based on personal beliefs of what is right and what is wrong. The moral choices exceeded the societal perspective and are elevated into a universal standpoint. The moral orientations turn to be "society-creating" rather than "society-maintaining". The post-conventional morality does not view what is right or wrong as an absolute concept to be taken for granted, rather, the concept of right and wrong is subjected to arguments, debates, and compatibility, and it is determined by the degree of acceptance. (Rest et., 1999, p. 41). This level also comprises of two stages:

The first stage is known as Social Contract Orientation. In this stage, individuals perceive "the right" as supporting the primary rights, values, or beliefs of the individual, even if those rights contradict with the present laws and rules of the social group. The individual is conscious of the rights and values that everyone should enjoy in a moral society.

Moral behavior in a particular situation is not determined by relating to a list of laws but from rational employment of universal moral beliefs. The individual's natural rights and privileges are a priority to society and must be shielded by society. This perspective creates a different and most likely opposing view between the morality of the individual and his society. The social group is viewed as a social contract between the individual and the collective. (Kohlberg, 1981, p. 382).

The next stage in this level is known as the Universal Ethical Orientation. If an individual reaches this stage, the universal principles define his/her actions. Equality and worth of living are a right for every human being. In this stage, the individual puts himself in other's shoes and takes the role of every other individual in a given situation. Choosing the right action is a matter of universal morality. The individual identifies and acts out of universal respect for all human beings, asserting that every human is precious and entitled to be dressed with dignity and justice. Martin Luther King Jr., is an example of this stage.

\subsection{Analysis}

\subsubsection{Jane's Preconventional Morality}

In Kohlberg's (1958) pre-conventional level of moral reasoning, the concept of 'right' and 'wrong' is "a matter of personal values and opinion" (p.1067). According to Kohlberg (1958), in the first stage of this level there is always the fear of punishment; hence, the child tends to obey rules in order not to be punished. The main concern of this stage is to stay safe and to avoid pain 
where the individual is driven by his egocentric and his own interests rather than the interests of the society (Kohlberg, 1984). Kohlberg believes that in the pre-conventional stage, the individual seeks to care for self and strives to keep secure at any cost, and there is also a sense of selfishness at this stage. This stage does not consider the interests of other members of society. It is incapable of making a relation to another's viewpoint (Kohlberg, 1984).

After the death of her uncle, Jane does not feel safe at Gatesheed house. Mrs. Reed and her three sons are not really willing to host Jane or accept her as a family member. On the contrary, Jane is always subjected to blame and punishment either guilty or not. Jane is aware that she is considered as an undesired outsider who is not welcome to the family, so she restlessly strives to keep herself safe and not to stir anyone's hostile feelings. In order to stay safe, Jane seeks to hide herself and stay away from punishment. In one occasion, she takes a book and starts reading it on a seat where she draws the "red moreen curtain nearly close, I was shrined in double retirement." (Brontë, p. 8). Jane is more interested in hiding than in reading the book, and she hopes that no one will notice her absence. Being out of sight is one of Jane's strategies to avoid punishment as Kohlberg (1984) states there is always the fear of punishment and the individual learns to care for self and seeks to survive at any cost. Unfortunately, her cousin Liza notices her, and John asks her to get closer to him. Although Jane knows that John hates her, and he is used to punishing her three times or more in a week, she obeys his order hoping if she does so, he might not have an excuse to punish her. Again, Jane believes that obeying authority might be the right decision to make in order to stay safe. However, contrary to her hope, her belief is sound; John hits her with the book she reads and her blood sheds over her neck, announcing the start of her rebellion to be free. Jane's blood stirs "different feelings" (Brontë, p.15) where she for the first time fights back. Jane's action against John is viewed as a wicked, unfamiliar behavior which needs to be treated soon. So, Mrs. Reed asks the servants to lock Jane in the red room. The servants take her to the red room where her uncle died as a kind of punishment to treat her body and soul, as Mrs. Reed tells her after. However, in the red room, the servants tend to tie Jane to the chair so as not to move which makes Jane cry, 'I will not stir.' In guarantee whereof, I attached myself to my seat by my hands" (Brontë, p. 17). Jane now does not seek to avoid the punishment but seeks a lesser punishment. While in the red room, Jane addresses herself wondering why she is treated badly even though she follows the rules and regulations in the house in an attempt to please Mrs. Reed. She does not understand why she is punished while her cousins get rewarded even when they break the rules. "I dared commit no fault: I strove to fulfil every duty; and I was termed naughty and tiresome, sullen and sneaking, from morning to noon, and from noon to night." (Brontë, p.22). Jane's moral reasoning at this stage does not go further than seeking the reason she is treated badly for. She does not really understand her position:- she just feels wronged.

Falling in the preconventional stage of moral reasoning, Jane asserts her tendency to avoid punishment in different ways. Driven by her egocentric force, she starts thinking of paying a very high cost for her redemption; to escape the oppression or to kill herself. This kind of reasoning is emphasized in Kohlberg's theory. The red room reveals a lot of Jane's moral thinking, her ability to distinguish between right and wrong perfectly fits the first stage of Kohlberg's diagram where the individual does what he thinks is right in order not to be hurt. Because Jane cannot simply avoid being punished, she begs to be punished in some other less harmful ways ' $\mathrm{O}$ aunt! [h]ave pity! Forgive me! I cannot endure it - let me be punished some other way!’ (Brontë, p. 28). 
When Mr. Brocklehurst asks Jane how she can avoid going to hell, she tells him she "must keep in good health and not to die" (Brontë 34). Jane's naïve strategy to avoid biblical punishment reveals her childish moral reasoning that if she is not to be punished in hell, she must not die. She believes that the right thing to do is to stay healthy. However, before being sent to Lowood School, Jane confronts her aunt and reveals her true feelings of hate and anger where she for the first time feels strong and free, but soon she realizes her immoral reaction when she states "its after-flavor, metallic and corroding, gave me a sensation as if I had been poisoned." (Brontë, p. 66). Jane feels guilty for being immoral that she thinks of apologizing to her aggressive aunt who never misses an opportunity to punish Jane.

As a poor orphan, Jane is lower than the servants in the Reed family. She is totally different from them, both in nature and in interests. As a child, she grows angry and disdains their judgment over her. Despite the Reeds' insulting and harsh treatment, Jane develops a strong sense of self, and is determines to seek independence.

During her stay at Gatesheed, Jane is indeed willing to conform to the expectations of the authoritarian power represented by her aunt so as to avoid punishment, but being punished with or without reason makes Jane act oppositely. She might rebel against the unjust treatment, but this rebellious attitude is not naturally innate, rather, it is a reaction to unjust actions. Ironically, Mrs. Reed asks Jane to lead a "natural" child behavior. Although, her children learn to conform to expectations, they demonstrate hypocrisy in their manners to Jane and even their behavior with their mother. The novel's consistent juxtaposition of social expectations with true morality thus opens with the contradiction between Jane and the Reed children. The children's aggressive behavior toward Jane is never questioned. Thus, Jane understands and scorns her aunt's selfindulgence and hypocrisy and refuses to obey her unworthy authority. As a result, Mrs. Reed labels Jane as a deceitful child when Mr. Brocklehurst comes to take her to Lowood School, and she warns him to keep an eye on her and to be strict with her. Mrs. Reed said "I should be glad...keep a strict eye on her, and, above all, to guard against her worst fault, a tendency to deceit. (Brontë, p.57). Mrs. Reed is not entirely satisfied with her cruel actions towards Jane:- She hopes that Lowood School will teach Jane how to submit to discipline, rules, and distinguish the difference between right and wrong behaviors.

\subsection{Jane's Conventional Morality}

At the first stage of this level, which is the good girl/ boy; children from ages (8-16) shift from their pure egocentric interests to please older people in authority, such as parents, teachers, and usually friends (Kohlberg, 1984). The goal of this stage is to elevate to the expectations of others and behave well to gain approval.

For most women of the Victorian-epoch, staying at home and conducting family concerns, as well as rendering comfort and satisfaction for their husbands, were essential duties. Tyson (2014) demonstrates this patriarchal paragon as an idea perceived as the angel of the house and declares that Victorian women are viewed in two perspectives; the good or the bad girl. She also 
states that the model of the good girl is the one who "accepts her traditional gender role and obeys the patriarchal rules" while the bad girl is "violent, aggressive...[and] monstrous" (p. 89). Consequently, the woman who does not abide by the patriarchal rules is labelled a monster.

Jane tries hard to be the good girl in Gatesheed to gain a natural social position as any child and a "more attractive and sprightly manner, something lighter, franker, more natural as it were" (Brontë, p.8), but it seems that she is always viewed as not good enough. Jane, the narrator, describes how the Reeds treat her "I was a discord in Gatesheed Hall: I was like nobody there" (Brontë, p. 43), and she believes it might be her unbeautiful appearance that makes the Reeds reject her. Jane assumes that due to her low social position and because she is not a pretty girl, she deserves to be treated in such an unjust ways. The threat of being sent to the "poor-house" makes Jane obedient, and she tries "to make [herself] agreeable to them" (Brontë, p.18). When she is locked in the red room for defending herself against John who is used to beating her, Jane realizes that the bad treatment she receives has nothing to do with her behavior, because her cousin John goes unpunished for the same behavior. The unfair treatment urges Jane to rebel against the oppressive society, especially the patriarchal society, who expects Jane to be a submitted typical Victorian woman, but Jane rejects to admit this arrangement. When Mrs. Reed recognizes that she is unable to control Jane, she decides to send her to a more rigid and tougher environment to teach her "conformity to her position and prospects" (Brontë, p.60).

The dispatch of Jane to Lowood School is not but a desperate attempt and great unfulfilled expectation to break Jane's pride and prejudice. Those hopes have gone with the wind as for the first time, Jane finds herself surrounded by a fair number of teachers and students who treat her fairly and equally. In order to have the greatest number of friends, Jane works hard to be a good girl, seeking respect, justice, equality, and affection. Although Mr. Brocklehurst's warnings to the students and the teachers that Jane is a deceitful and bad girl and urges them to stay away from her, Jane does not hesitate to be a good girl who captures the hearts of others despite her fear of them believing him. Despite the very bad conditions at Lowood School, it is still a good start for Jane to prove herself as a good girl "I had meant to be so good, and to do so much at Lowood, to make so many friends, to earn respect, and win affection” (Brontë, p. 68). It is obvious that Jane's desire to be a "good" girl is striking and insistent, especially when she tells her friend, Helen Burns, that thinking well of herself does not satisfy her if she does not gain love from others. Jane wants to be loved by those around her because she knows that she will not gain a natural social position unless others love and accept her. She prefers death than to be hated. Helen does not appreciate Jane's pursuit humanly love and affection, but Jane is willing to sacrifice herself for that

I would willingly submit to have the bone of my arm broken, or to let a bull toss me, or to stand behind a kicking horse, and let it dash its hoof at my chest" in order to "gain some real affection from you, or Miss Temple, or any other whom I truly love (Brontë, p. 129).

Jane is not satisfied with the fact that she is a good girl unless approved by those around her, she wants to prove to others that she is not as Mr. Brocklehurst claims. Jane's good relationship with the other girls and the teachers makes her capable of overcoming Mr. Brocklehurst's tyranny, and she comes to realize that she is inherently a good girl. She also comes to realize that in order to be a functional individual in the bigger society, she needs to show goodness. Miss Temple is a good 
model for Jane to follow; Miss Temple offers Jane the chance to defend herself against Mr. Brocklehurst's accusation of being a liar (Brontë, p.71). Miss Temple then clears Jane from any wrongness after receiving a conformation from Mr. Lloyd, the doctor who treated Jane at Gatesheed. This incident makes Jane flourish and teaches her that her determination to be a good girl will guarantee respect and affection. Miss Temple encourages Jane to be a good girl when she instructs her to conduct herself accordingly to satisfy her and those around her. For Jane to prove her goodness, she works and studies hard because she knows that her teachers will admire her efforts as a good student. Jane's efforts are crowned by elevating her to a higher class in the school and she gains her teachers' affection and support. Miss Temple's kind treatment makes Jane see Lowood with its physical deficiencies as a better place than the luxurious, but terrifying Gatesheed where she experiences no love, friendship, or affection.

Even though Jane opposes many of Helen's beliefs, she unwillingly takes Helen's advice to endure punishment: "It was as if a martyr, a hero, had passed a slave or victim" (Brontë, p.124). This endurance of punishment indicates Jane's strong desire to be viewed as a good and obedient girl. It is worthy to say that Jane endures the punishment but does not accept it. By trying to act well and be a good girl in order to satisfy upper authority, Jane is a typical model of Kohlberg's first stage of conventional moral development. The right and wrong concept is determined by being labeled either a good or bad girl. Jane strives hard to be the good one.

The second stage of this level is concerned with conformity to social rules. At the age of eighteen, Jane, unlike the conventional Victorian woman, does not move to a husband's house. Instead, she moves to Thornfield to be a governess for the little Adele. Being a governess is not an easy position to occupy for a middle class Victorian woman. This stage of moral development trims most of Jane's moral codes since her behavior, actions, and decisions are the result of mixed social conventions, conformity and self-respect.

Jane moves to Thornfield to work as a governess where she falls in love with Mr. Rochester and soon their wedding is planned. However, Jane comes to know that Mr. Rochester is already married to the lunatic Bertha Masson and if she agrees to marry him, she will be breaking the law and the religious interpretations. Law and religion do not allow a man to have two wives. Bennett (1978) declares it is religiously and legally wrong for a woman to live with an already married man, under any circumstances. Jane also understands that she will be despised by social conventions. These three authorities prevent Jane and Rochester to be spouses. Jane abides by these rules and states that "I will keep the law given by God; sanctioned by man" (Brontë, p. 319). In this quotation, Jane makes clear that her moral integrity is more abided by legal, religious, and social laws rather than her own feelings.

Although Jane is almost convinced by Rochester's argument for staying with him, she realizes that she would be scorned by society. Being a mistress is never accepted by religious or social norms as Henry Mayhew, puts it ". . . any woman who lived or had sexual relations with a man outside of marriage was a prostitute" (Poovey, 2009, p. 131). For Jane, it is not possible to go against the rules if they are to protect her reputation. Rochester tries to insist that Jane can discard conventional morality since she is an orphan with no family to be offended by her decision, but she recognizes that she has to make the right decision and do the right thing which is not to marry 
him. This is a clear indication of Jane asserting her conventional morality and not compromising her moral codes. Jane's moral codes are the guide of her journey towards maturity and selfactualization especially when she is under pressure to make a decision. This quotation also shows how Jane's sense of conventional morality guides her to make right choices and distinguish between what is right and what is wrong. It is worth noting here that although Jane opposes social values that restrict her independence or make her subject to masculine powers, she adheres to these laws as long as they serve the concept of right and wrong. Jane is able to balance what is right and wrong, and she differentiates between the concept of defying societal values or submitting to them.

The concept of "conventional morality" (Basch, 1974, p. 171) is "internalized" in Jane (Figes, 1987. p. 114). Although Jane is in deep love with Rochester, this love is not blessed by all laws, which prevent a man to have two wives. Jane dare not to violate the laws. "Laws and principles are not for the times when there is no temptation" (Brontë, p.606). To marry Rochester is impossible for her and she refuses to join him as a mistress out of her moral judgment. Rochester's temptations are far from changing her moral values, so she decides that her flesh and blood are to leave Thornfield while her heart is to stay. Craik, (2011) states that Rochester "tempted her to violate her moral standards" (p.100), but her conscience warns her against it. Bernard (2013) describes Jane's inner moral conflict as a regulation between mind and desire, while Scargill (1950) describes it as an "eternal conflict between the flesh and the spirit" (p.121). Jane describes leaving Rochester as 'It was a barbed arrow-head in my breast' (Brontë, p. 613). However, she prefers to sacrifice her feelings to meet the rules of the law even if that means torturing herself. Jane's fleeing of Thornfield protects her from psychological disintegration and moral degradation and permits her to warrant her will. Jane makes a series of tough moral choices, none more pressing than to leave Rochester. Outweighing moral and social commitment over her feelings, Jane leaves Rochester who opposes all constitutional, theological and cultural rules. Because he believes that he and Jane are in true deep love, he dares to create his own morality and reject the already existing morals. Although Rochester is the most influential in Jane's journey, she never argues about her moral identity. What is right or wrong is unnegotiable. Jane's focus is more on avoiding chaos and the unstructured deconstruction of the society.

\subsection{Jane's Post-conventional Morality}

The seeds of moral judgment and reasoning are getting their fruits in the post-conventional stage of moral development. When Jane arrives at Moor House, Hannah deprecatorily and bluntly inquiries her social position: "Did you ever go a-begging afore you came here?" (Brontë, p. 651). Hannah believes that Jane is a lower-class beggar. She even believes that beggars are criminals. However, when she realizes that Jane is none of what she assumes, she begs Jane not to judge her harshly. But Jane is harsh in her response not because Hannah does not shelter her, but because she refers to poor people as criminals. Jane strongly believes that being poor is not a crime and true Christians do not consider poverty a sin. Jane's response is not an act of self-revenge but an act of universal respect and equality for all people no matter what their social status is. This reasoning makes Jane act in the post-conventional morality of Kohlberg's theory where right and wrong is determined by a universal view that seeks justice and equality for all. The same attitude arises against Rochester when Jane earlier tells him that the poor are not less or inferior to their superiors. Of course, as Jane tells, this attitude is not based on conventional beliefs or customs, but rather based on a belief that goes beyond all material considerations, something highly elevated 
known as the post-conventional morality. Jane's moral defense of the poor is the result of accumulated circumstances and experiences she has to deal with unconsciously as a child and consciously as an adult. Jane's moral development is a chronological understanding of what is right and wrong. As a child she did not want to go to the "poor house" because poverty used to mean rough clothes, insufficient meals, cold relationships, rude behaviors, and degrading vices. For Jane, poverty used to mean "degradation" (Brontë, p, 40). As an adult, she comes to realize that poverty is not a vice, and it does not hinder virtue. Jane is quite truthful when she recoils from the moral degradation and when she advocates the moral integrity of the lower class and poor people.

St John acts another moral dilemma for Jane when he asks her to marry and join him to India as a missionary. He warns her that if she rejects his proposal, it would be a rejection of God. St. John is degrading love to a gloomy duty, and he imposes the burden of guilt upon her if she denies the noble duty he offers. However, Jane remains sincere to her individuality and to her heart and morals and refuses the proposal. Once again directed by a higher level of reasoning and moral beliefs, she does not violate her morals to accept St. John's abstract concepts of devotion. Jane disdains this distorted obscure sense of love that disregards the feelings of the heart. She feels no responsibility to join him to India as a wife because she believes that God has given her a life to be appreciated and respected, she believes if she accepts St. John's proposal, she will be throwing her life away which is a matter of suicide. This incident shows the extreme change in Jane's reasoning where at the beginning of her story, she thinks of suicide to get rid of punishment, but now she rejects the idea and believes that she has a life to live. Jane does not adhere to the tradition of love either in the frame of uncontrolled emotions or self-denial. In the time that Jane rejects Rochester's proposal out of conventional morality, she rejects St. John's proposal out of postconventional morality where rights take priority over what others believe (Kohlberg, 1984). Within the inner conflict between love and duty, Jane express her feelings in both cases when she say "To have yielded then would have been an error of principle; to have yielded now would have been an error of judgment. (Brontë, p. 802).

By "then" Jane refers to the past time of intense difficulty of temptation she encountered in her strong wish to stay with Mr. Rochester as a mistress, a decision that could have broken her moral principles to which she resumes to stick through her journey. For her, however, the alarming outcomes of "an error of principle" include more than simply a fear of God's punishment. To have compromised her moral beliefs for Mr. Rochester, she affirms, would have destroyed herself, and just as "now" to yield to St. John's wish, would be a wrong moral decision. Seemingly, St. John wants to marry Jane and be his lawful wife, which is the extreme opposite of Rochester's offer. It might seem confusing for the reader that Jane rejects both, but a deeper investigation reveals that Jane is progressing from a conventional moral reasoning to a post-conventional judgment. Jane's rejection of both proposals is based on different perspectives of moral thinking. The former is based on conformity to social and religious regulations while the latter is paradoxically based on confrontation of these regulations. The confusion between conforming to and confrontation with laws is a healthy state of making decisions in Kohlberg's moral development where the individual does not always have to yield to laws as long as they hinder his rights. For Jane, love is an essential priority from the very beginning of her journey, and she is not willing to sacrifice it at any cost now. Brontë meant to create a character who is bendable but unbreakable to conventions. 
In another situation that highlights Jane's sense of the highest level of postconventional morality is when she decides to equally divide the sum of money she inherited between herself and her relatives. St. John himself does not understand this kind of behavior. Jane is aware that the money is legally hers, but in the sense of justice it is not. Jane explains that "it would torment and oppress me to have twenty thousand; which, moreover, could never be mine in justice, though it might in law" (Bronte, p. 868). Jane does not only believe that keeping the whole sum of money for herself is a kind of oppression, but also a kind of selfishness and injustice. Her universal view of justice and equality put her in the highest level of Kohlberg's chain of moral development. Jane's moral development was woven skillfully that many contradictions and extremes could have hindered it, but the protagonist manages to overcome all the opposites. According to McFadden (1996), Jane goes against the expected type of woman by rejecting the submission, opposing her superiors, fighting for her rights, and being courageous enough to come up with new, unfamiliar thoughts. Jane is morally conscious that she is able to make challenging decisions which drive her to achieve her full maturity. At the end of her journey, Jane returns to her heart at Thornfield, where Mr. Rochester is no longer engaged with another woman since his legal wife is dead. Jane simply marries Mr. Rochester and they have a child.

\subsection{Conclusion}

This paper presents how the main character progresses morally from the early stages as a poor dependent girl into a fully matured wife. Through a series of social and moral dilemmas, Jane is capable of creating a balance between adhering to and rejecting the social norms that might hinder her maturity. It also illustrates how the other characters in the novel affected her moral development. During her journey, Jane could develop a sense of what is morally right and what is wrong. Since moral development is an essential component of the bildungsroman novel, Jane Eyre is a perfect model of this type of genre. Through her journey, Jane achieves the most important ingredient of the bildungsroman, which gives the novel a sound credit to be classified as such. Bronte brilliantly presents Jane as a character who develops a strong sense of moral development against injustice. Jane is a protagonist who thinks, feels, and acts out of moral reasoning which leads her to distinguish between what is right and what is wrong and makes decisions accordingly.

\section{About the Authors:}

\section{Ali Abu Hassan}

Ali Abu Hassan is a PhD student in English Language Studies at Sultan Zinal Abidin Universiti, Kuala Terengannu, Malaysia. He is also a lecturer of English Language at the Northern Border University (Saudi Arabia). He is also a secondary school English teacher (Jordan). His main area of interest is English Literature. ORCID ID: https://orcid.org/0000-0001-8735-0908.

\section{Dr. Mohammad Nazri Bin Latif Azmi}

Dr. Nazri's specializations are on literacy and comparative literature studies. He attended several long-term professional courses in education and comparative literature in the USA and Portugal. He has been a keynote speaker at several international conferences in Asia and presented more than 15 papers inside and outside Malaysia and published more than 20 papers in indexed journals. His passion towards education and literature is overwhelming due to realizing that language is a beautiful art and education is the root of any civilization. 


\section{References}

Basch, F. (1974). Relative creatures: Victorian women in society and the novel 1837 - 67. London: Lane.

Bennett, J. (1978). George Eliot: Her mind and art. London: Cambridge University Press.

Bernard, R. (2013). The accents of persuasion: Charlotte Bronte's novels. Faber \& Faber.

Bronte, C. Jane Eyre. Planet PDF. Accessed from http://www.planetpdf.com.

Colby, A., \& Kohlberg, L. (1987). The measurement of moral judgment: Vol. 1. Theoretical foundations and research validation. New York: Cambridge.

Craik, W. A. (2011). The Brontë novels. London: Routledge.

Figes, E. (1987). Patriarchal attitudes. New York: Persea Books.

Hayes, J. R. (2013). The Complete Problem Solver. Hoboken: Taylor and Francis.

Hirsch, M. (1979). The Novel of Formation as Genre: Between Great Expectations and Lost Illusions in Studies in the Novel. Genre Norman NY, 12(3), 293-311.

Kohlberg, L. (1958). The development of modes of moral thinking and choice in the years 10 to 16. University of Chicago.

Kohlberg, L. (1971). From is to ought: How to commit the naturalistic fallacy and get away with it in the study of moral development. Place of publication not identified: publisher not identified.

Kohlberg, L. (1981). Essays on moral development: The philosophy of moral development (Vol.I): Moral stages and the idea of justice. San Francisco: Harper and Row.

Kohlberg, L. (1984). Essays on moral development: Vol. 2. The psychology of moral development: The nature and validity of moral stages. San Francisco: Harper \& Row.

Kuhmerker, L. (1991). The Kohlberg legacy for the helping professions. Birmingham, Ala: Religious Education Press.

McFadden, M. (1996). Critical Evaluation. Masterplots. Rev. 2nd edition. Vol. 6. Ed. Frank N. Magill. Englewood Cliffs: Salem Press, 1996: 3290-4.

Murfin, R. C, \& Ray, S. M. (1997), The Bedford glossary of critical and literary terms. Boston Books.

Poovey, M. (2009). Uneven developments: The ideological work of gender in mid-Victorian England. University of Chicago Press.

Power, F. C. (2004). The moral self in community. In Moral development, self, and identity (pp. 59-76). Psychology Press.

Rest, J. R., Thoma, S. J., \& Bebeau, M. J. (1999). Postconventional moral thinking: A neoKohlbergian approach. Mahwah, NY: Lawrence Erlbaum.

Reynolds, S. J., \& Ceranic, T. L. (2007). The effects of moral judgment and moral identity on moral behavior: an empirical examination of the moral individual. Journal of Applied Psychology, 92(6), 1610.

Scargill. (1950). "All Passion Spent": A Revaluation of Jane Eyre. University of Toronto Quarterly, 19(2), 120-125.

Talwar, V. (2011). Moral Behavior. In Encyclopedia of Child Behavior and Development (pp. 965-967). Springer, Boston, MA.

Tsui, J., \& Windsor, C. (2001). Some cross-cultural evidence on ethical reasoning. Journal of Business Ethics, 31(2), 143-150.

Tyson, L. (2014). Critical theory today: A user-friendly guide. Routledge. 